\title{
Quality characteristics of dumpling shell added with dropwort powder
}

\author{
Geum-Soon Park*, Ji-Young Kim \\ Faculty of Food Service and Technology, Catholic University of Daegu, Gyeongsan 712-702, Korea
}

\section{미나리 분말을 첨가한 만두피의 품질특성}

\author{
박금순* · 김지영 \\ 대구가톨릭대학교 생명식품학부 외식산업학과
}

\begin{abstract}
We investigated quality changes in dumpling shells by addition of various concentrations of dropwort powder. Dumpling shells were added with $0,1,3,5$, and $7 \%$. dropwort powder respectively. Their water-binding capacity, weight, volume, and turbidity increased after cooking. As the added dropwort powder increased, their DPPH radical scavenging activity significantly increased $(\mathbf{p}<\mathbf{0 . 0 0 1})$. In addition, their $L$ and a values decreased whereas their b value increased. In terms of the textural characteristics, the hardness and springiness increased and the cohesiveness and brittleness of the cooked dumpling shells significantly increased with an increasing content of dropwort powder. The savory taste, moisture, and chewiness of the dumpling shells prepared with the addition of $3 \%$ dropwort powder were preferred. Overall, the sensory evaluation showed that the sensory characteristics of the dumpling shells were best with the addition of $3 \%$ dropwort powder.
\end{abstract}

Key words : dumpling shell, dropwort powder, quality characteristics

\section{서 론}

만두는 우리나라 주식류의 한 종류로 하루 세끼 식사 중 점심이나 저녁에 식사 대용으로 먹기도 하며 간식 또는 별식으로 남녀노소 구분하지 않고 즐겨먹는 음식이다(1). 또한 한국인의 식습관에 가장 적합한 특징으로 원료 및 형태에 따라 다양한 제품의 구현이 가능하기 때문에 향후 지속적인 성장이 가능한 품목군으로 평가되고 있다(2). 특 히 가정에서 뿐만 아니라 단체급식에서도 자주 제공되는 음식 중 하나로(3) 간편 영양식으로 선호하며, 단체급식에 서도 자주 제공되는 음식 중 하나로 소비자들의 다양한 요구에 맞는 만두피의 개발이 지속적으로 필요하다(4). 특 히 만두는 냉동상태에서 유통, 보존해야하며, 만두피는 반 죽하는 방법, 시간, 날짜 및 습도 등에 크게 영향을 받기

*Corresponding author. E-mail : gspark@cu.ac.kr

Phone : 82-53-850-3512, Fax : 82-53-850-3512

Received 15 October 2014; Revised 6 April 2015; Accepted 7 April 2015.

Copyright (c) The Korean Society of Food Preservation. All rights reserved.
때문에 만두피에 대한 다양한 연구 및 개발의 필요성이 제시된 바 있다(5).

한편 현대 식생활양식의 변화, 사회의 고령화, 외식의 증가에 따른 영양불균형으로 여러 가지 건강상의 문제가 야기되고 있으며 성인병 예방을 위한 기능성 식품에 대한 연구가 활발히 진행되고 있다. 기능성 재료를 첨가한 만두 피에 대한 연구로는 볶은 콩가루 첨가 만두피(6), 홍어분말 을 첨가한 만두피(4), 새우 분말을 첨가한 만두피(7) 파래분 말을 첨가한 만두피(8), 새송이버섯 분말을 첨가한 만두피 (9), 비파잎 분말을 첨가한 만두피(1), 울금분말을 첨가한 만두피(10)에 대한 특성 연구가 보고된 바 있다. 이에 소비 자들이 즐겨 찾는 만두의 만두피를 제조할 때 생리활성 효과가 있는 식재료를 첨가하여 제조하면 소비자의 건강에 도움이 되며 좋은 냉동 식품을 개발 할 수 있을 것으로 사료된다.

미나리(Oenanthe javanica)는 미나리과에 속하는 다년초 초본으로 예로부터 채식 위주의 식생활을 영위하여 온 우리 민족에게 있어서 큰 비중을 차지하는 식량 자원이다(11). 한국, 일본, 중국, 대만, 말레이사, 인도 등지에 분포하며 우리나라 농가에서도 많이 재배되고 있는 식물로 식품 영양 
학적으로 플라보노이드 화합물 뿐 아니라 비타민과 칼륨, 칼슘 및 철분이 들어있는 대표적인 식품이다(12). 미나리는 우리나라 사람들이 좋아하는 향채 중의 하나로 식욕을 되찾 는 식품으로 이용되며 독특한 향미 및 약리작용으로 인해 기능성 식품 소재나 향신료로 활용도가 높은 약용식물이다 (13).

미나리의 엽경은 한방요법으로 지혈, 강장, 정력보강, 보 혈, 이뇨, 주독, 폐렴 등에 사용되며 혈압강하, 해열, 진정, 변비예방, 일사병 및 하혈 등에도 효과가 있는 것으로 알려 져 있다(11).

미나리에 관한 연구로는 미나리의 형태적 특성 및 성분 에 관한 연구가 활발히 보고되고 있으나 식품에 이용한 연구로는 부추 및 미나리 건조가루를 첨가한 국수 품질에 관한 특성(14), 미나리 첨가가 castella의 품질에 미치는 영 향(15), 미나리 가루를 첨가한 설기떡의 품질특성(16) 이외 에 미흡한 실정이다. 따라서 한국인에게 약용 및 식용 식물 로서 높은 가치를 지닌 미나리를 만두피 제조시 첨가하여 품질 특성을 평가하고 제품 개발을 위한 기초자료로 활용하 고자 한다.

\section{재료 및 방법}

\section{실험 재료}

본 실험에는 밀가루(Midium wheat flour, Daehan flour mills Co., Ltd., Korea), 소금(Taehwa, Teongcheon, Korea)을 사용하였고 미나리 분말(Palgongsan minari neugsung youngnong, Daegu, Korea)에서 구입하여 분말류의 재료는 40 mesh 체에 내린 후 사용하였다.

\section{일반성분 분석}

밀가루와 미나리분말의 일반성분은 $\mathrm{AOAC}$ 법(17)으로 측정하였다. 수분함량은 $105^{\circ} \mathrm{C}$ 상압가열건조법, 조단백질 은 micro-Kjeldahl법, 조지방 함량은 Soxhlet 추출법, 회분은 전기로 온도 $550^{\circ} \mathrm{C}$ 에서 회화시켜 직접 회화법으로 측정하 였다.

\section{만두피의 제조}

미나리 분말의 첨가비율을 달리하여 제조한 만두피의 품질 특성을 살펴보기 위하여 예비실험을 거쳐 Table 1과 같은 기본 배합성분 및 양으로 제조하였다.

만두피 반죽은 밀가루 $100 \mathrm{~g}$ 에 소금 $2 \mathrm{~g}$, 물 $45 \mathrm{~g}$ 과 밀가루 대비 미나리 분말 $0,1,3,5,7 \%$ 를 첨가하여 반죽 후 상온에 서 30 분간 숙성시킨 뒤 가정용 국수 제조기(ATLAS, Marcato, Italy) 이용하여 두께 $1.0 \mathrm{~mm}$, 직경 $5.0 \mathrm{~cm}$ 의 원형 만두피를 제조하였다.
Table 1. Formula for the dumpling shell with varied levels of dropwort powder

\begin{tabular}{lccccc}
\hline \multirow{2}{*}{ Ingredient $(\mathrm{g})$} & \multicolumn{5}{c}{ Sample $^{1)}$} \\
\cline { 2 - 6 } \multicolumn{1}{c}{ Flour } & $\mathrm{S}$ & $\mathrm{D} 1$ & $\mathrm{D} 3$ & $\mathrm{D} 5$ & $\mathrm{D} 7$ \\
\hline Dropwort powder & 100 & 99 & 97 & 95 & 93 \\
Salt & 0 & 1 & 3 & 5 & 7 \\
Water & 2 & 2 & 2 & 2 & 2 \\
\hline
\end{tabular}

${ }^{1)}$ S, Dumpling shell added 0\% dropwort powder; D1, Dumpling shell 1\% dropwort powder, D3, Dumpling shell 3\% dropwort powder; D5, Dumpling shell 5\% dropwort powder; D7, Dumpling shell 7\% dropwort powder.

수분 결합 능력 (water binding capacity, WBC)

수분 결합 능력은 시료 $2 \mathrm{~g}$ 에 증류수 $20 \mathrm{~mL}$ 를 가하고 magnetic stirrer로 1 시간 교반 후 $3,600 \mathrm{rpm}$ 으로 20 분간 원심 분리를 하였다(18). 그 후 상등액을 제거한 침전물의 무게를 측정하여 처음 시료량과의 중량비로 다음과 같이 수분결합 능력은 계산하였다.

$$
\text { 수분결합능력 }(\%)=\frac{\text { 침전 후시료무게 }(g)}{\text { 처음시료무게 }(g)} \times 100
$$

만두피의 조리특성

만두피의 조리시 변화에서 중량의 변화는 만두피 $50 \mathrm{~g}$ 을 끓는 물 $400 \mathrm{~mL}$ 에 넣고 3 분간 삶은 후 30 초간 냉수에서 냉각시키고 3 분간 물을 뺀 뒤 만두피의 무게를 측정하였다. 수분 흡수율은 조리 후 만두피의 중량에서 생만두피의 중량 을 빼고 다시 생만두피의 중량으로 나눈 후 100 을 곱하여 계산하였다. 삶은 만두피의 부피는 $500 \mathrm{~mL}$ 메스실린더에 증류수 $300 \mathrm{~mL}$ 를 채운 후 수분 흡수율을 측정한 만두피를 시료로 넣어 증가하는 물의 부피를 측정하였다. 만두피 국 물의 탁도는 냉각 후 spectrophotometer(Optizen 3220UV, Mecasys Co., Daejeon, Korea)를 이용하여 $675 \mathrm{~nm}$ 에서 흡광 도를 측정하였으며 모든 실험은 3 회 반복하여 실시하였고 평균으로 나타내었다.

\section{$\mathrm{DPPH}$ radical scavenging 측정}

만두피의 항산화성을 알아보고자 시료 $10 \mathrm{~g}$ 과 에탄올 $20 \mathrm{~mL}$ 를 첨가하여 교반시켜 원심분리 한 후 $\mathrm{DPPH}$ (1,1-diphenyl-2picriylhydrazyl, D9132, Sigma-Aldrich, St. Louis, USA) $0.1 \mathrm{mM}$ 용액과 혼합하여 30 분 후 $517 \mathrm{~nm}$ 에서 흡광도를 측정하였다. 항산화 효과는 시료 용액 대신 같은 양의 에탄올을 대조구로 하여 실험구와 비교하여 다음과 같이 분석하였다.

항산화 효과 $(\%)=1-(\mathrm{A} / \mathrm{B}) \times 100$

$\mathrm{A}$ : 시료 첨가구의 흡광도, $\mathrm{B}$ : 무첨가구의 흡광도 
색 도

만두피의 색도는 만두피를 끓는 물에 넣고 3 분간 삶은 후 물을 뺀 뒤 측정용기에 담아 색차계(CR 400, Konica Minolta Inc., Tokyo, Japan)를 사용하여 L값(명도), a값(적색 도), $\mathrm{b}$ 값(황색도)을 3회 반복 측정하여 평균값으로 나타내 었다. 이 때 사용된 표준백판의 $\mathrm{L}, \mathrm{a}, \mathrm{b}$ 값은 $94.61,-0.02$, 2.77 이었다.

\section{Texture}

원형 만두피를 Rheometer(Compac-100, Sun Sci Co., Ltd., Tokyo, Japan)를 이용하여 경도(hardness), 탄력성(springiness), 응집성(cohesiveness), 씹힘성(chewiness), 부서짐성(brittleness) 을 측정하였다. 측정조건은 plunger diameter $5 \mathrm{~mm}$ (No.25), table speed $120 \mathrm{~mm} / \mathrm{min}$, sample heigh $1 \mathrm{~mm}$, load cell 2 $\mathrm{kg}$, strain $90 \%$ 로 3회 반복 측정하여 평균치를 나타내었다.

\section{관능검사}

관능검사는 훈련을 통해 선발한 관능요원 20 명을 대상으 로 평가특성과 검사방법에 대해 충분히 교육 후 7점 척도법 (1점-가장약하다, 가장 기호도가 낮았다, 7점-가장 강하다, 가장 기호도가 높았다)으로 나타내었다. 시료는 원형 접시 (지름 $10 \mathrm{~cm}$ )에 담아 제공하였으며 평가항목은 외관 (appearance), 향(flavor), 맛(taste), 조직감(texture), 삼킨 후 느낌(after swallowing), 기호도(acceptability)항목으로 구성 되었다.

\section{통계처리}

분산분석(ANOVA) 및 다중범위 검정(Duncan's multiple range test)에 의해 유의성 검정을 하였으며, 모든 통계자료 는 computer program package인 SAS 9.1을 사용하였다

\section{결과 및 고찰}

\section{일반성분 분석}

본 실험에 사용된 밀가루와 미나리 분말의 일반성분측정 결과는 Table 2 와 같이 밀가루의 수분함량은 $10.50 \%$, 조단

Table 2. Composition of wheat flour and dropwort flour

\begin{tabular}{lcc}
\hline $\begin{array}{c}\text { Characteristics } \\
(\%)\end{array}$ & Wheat flour & Dropwort flour \\
\hline Moisture & $10.50 \pm 0.05^{1)}$ & $6.4 \pm 0.21$ \\
Crude protein & $12.73 \pm 0.03$ & $26.5 \pm 0.28$ \\
Crude lipid & $1.37 \pm 0.01$ & $3.5 \pm 0.01$ \\
Crude ash & $0.29 \pm 0.02$ & $17.7 \pm 0.03$ \\
Carbohydrate & $75.11 \pm 0.22$ & $45.9 \pm 0.13$ \\
\hline
\end{tabular}

${ }^{1)}$ Mean \pm SD of three determinations.
백질은 $12.73 \%$, 조지방은 $1.37 \%$, 회분은 $0.29 \%$, 탄수화물 은 $75.11 \%$ 였다. 미나리 분말은 수분함량은 $6.4 \%$ 로 밀가루 에 비해 낮게 나타났으며 조단백은 $26.5 \%$, 조지방은 $3.5 \%$, 조회분 $17.7 \%$ 로 밀가루의 성분보다 높게 나타났다. 탄수화 물은 $45.9 \%$ 를 나타냈으며 미나리 분말이 밀가루 분말보다 회분의 함량이 약 60 배 정도 높은 것으로 나타났다.

\section{수분결합능력}

미나리 분말 $0,1,3,6,7 \%$ 를 첨가한 만두피의 수분결합능 력은 Table 3 과 같다. 수분결합능력은 대조군이 $132.73 \%$ 로 가장 낮게 나타났으며 미나리 분말을 $1,3,5,7 \%$ 첨가할수 록 $141.67 \%, 143.67 \%, 145.33 \%, 148.67 \%$ 순으로 증가하는 경향을 보였다. 수분결합능력은 시료와 수분과의 친화성을 나타내 주는 것으로 이 때 결합된 물은 시료입자에 의하여 흡수되거나 시료입자의 표면에 흡착되는 것으로 보고된 바 있다 $(19,20)$. 본 실험에 사용된 미나리분말은 수분결합 능력이 $507.00 \%$ 로 밀가루(153\%)보다 높게 나타나 미나리 첨가구가 무첨가구에 비해 높게 나타났으리라 사료된다.

Table 3. Water binding capacity of the dumpling shell the addition of with dropwort powder

\begin{tabular}{|c|c|}
\hline \multirow{2}{*}{ Sample ${ }^{1)}$} & Variables \\
\hline & Water binding capacity $(\%)$ \\
\hline$S$ & $132.73 \pm 0.46^{(2)}$ \\
\hline D1 & $141.67 \pm 1.53^{\mathrm{d}}$ \\
\hline D3 & $143.67 \pm 0.58^{c}$ \\
\hline D5 & $145.33 \pm 0.58^{b}$ \\
\hline D7 & $148.67 \pm 0.57^{\mathrm{a}}$ \\
\hline F-value & $151.69^{* * *}$ \\
\hline
\end{tabular}

${ }^{11}$ S, Dumpling shell added 0\% dropwort powder; D1, Dumpling shell $1 \%$ dropwort powder; D3, Dumpling shell 3\% dropwort powder, D5, Dumpling shell 5\% dropwort powder; D7, Dumpling shell 7\% dropwort powder.

${ }^{2)}$ Mean \pm SD of three determinations, means with different letters are significantly

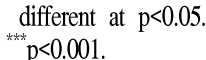

만두피의 조리특성

미나리 분말의 첨가량을 달리하여 제조한 만두피의 조리 특성은 Table 4와 같다. 만두피의 조리 후 중량을 살펴본 결과 대조군이 $8.80 \mathrm{~g}$ 으로 가장 낮게 나타났고 미나리분말 첨가구는 8.90 10.43으로 유의적으로 증가하였다 $(\mathrm{p}<0.001)$. 수분흡수율은 대조군에 비해 미나리분말 첨가구가 높게 나타나 미나리 분말 $7 \%$ 첨가 만두피가 가장 높게 나타났으 며 이는 미나리 분말의 높은 보수력 때문으로 사료된다. 마가루를 밀가루에 0 20\% 첨가 시 첨가량이 증가함에 따라 수분흡수율이 증가하였는데 이는 마가루의 보수력이 높기 때문이라 하여(20) 본 실험과 동일한 결과를 보였다. 홍어 첨가 만두피(4)에서는 수분흡수율이 62.31 87.33\%, 콩가루 
첨가 만두피 연구(6)에서는 $61.20 ~ 85.28 \%$ 로 나타나 부재료 에 따라 수분흡수율의 범위는 다르나 첨가재료의 첨가량이 증가할수록 본 실험과 유사하게 높게 나타나는 경향을 보였 다. 만두피의 부피는 미나리 분말 첨가 $5 \%$ 이상 첨가한 만두피 경우 유의적인 차이 없이 높게 나타났으며 대조군에 비해 미나리 분말 첨가구가 $\mathrm{p}<0.001$ 에서 유의하게 증가하 는 경향을 보였다. 콩가루를 첨가한 만두피의 경우 레시틴 과 단백질의 보수성으로 조리 특성이 높게 나타난다고 보고 (6)한 바 있는데 본 연구에서도 미나리 분말에 존재하는 단백질의 보수성으로 인한 결과로 사료된다. 탁도는 조리 중 고형분의 손실 정도를 나타내는 척도로 대조군이 0.153 으로 가장 낮게 나타났으며 미나리 분말 첨가량이 증가할수 록 용출 성분의 양이 많은 것으로 나타나 미나리 분말 $7 \%$ 첨가 만두피가 유의적으로 가장 높게 나타났다 $(\mathrm{p}<0.001)$. 이는 울금분말을 첨가한 만두피(10)와 파래분말 첨가 만두 피(8)에서 첨가량이 증가할수록 국물의 탁도가 높게 나타난 다고 보고한 바 있어 본 실험과 유사한 결과를 보였다.

Table 4. Cooking properties of the dumpling shell with the addition of dropwort powder

\begin{tabular}{ccccc}
\hline \multirow{2}{*}{ Sample $^{1)}$} & \multicolumn{4}{c}{ Cooking properties } \\
\cline { 2 - 5 } & Weight (g) & $\begin{array}{c}\text { Water absorption } \\
\text { ratio (\%) }\end{array}$ & Volume (mL) & $\begin{array}{c}\text { Turbidity } \\
(O D \text { at } 675 \mathrm{~nm})\end{array}$ \\
\hline S & $8.80 \pm 0.17^{\mathrm{c} 2)}$ & $52.60 \pm 0.24^{\mathrm{c}}$ & $78.00 \pm 0.20^{\mathrm{c}}$ & $0.153 \pm 0.00^{\mathrm{e}}$ \\
D1 & $8.90 \pm 0.10^{\mathrm{c}}$ & $52.67 \pm 1.46^{\mathrm{c}}$ & $78.30 \pm 0.10^{\mathrm{b}}$ & $0.199 \pm 0.00^{\mathrm{d}}$ \\
D3 & $10.10 \pm 0.10^{\mathrm{b}}$ & $55.21 \pm 0.72^{\mathrm{b}}$ & $79.97 \pm 0.06^{\mathrm{a}}$ & $0.215 \pm 0.00^{\mathrm{c}}$ \\
D5 & $10.13 \pm 0.12^{\mathrm{b}}$ & $55.94 \pm 0.48^{\mathrm{ab}}$ & $80.06 \pm 0.12^{\mathrm{a}}$ & $0.254 \pm 0.01^{\mathrm{b}}$ \\
D7 & $10.43 \pm 0.06^{\mathrm{a}}$ & $57.58 \pm 1.83^{\mathrm{a}}$ & $80.23 \pm 0.29^{\mathrm{a}}$ & $0.339 \pm 0.00^{\mathrm{a}}$ \\
\hline F-value & $131.18^{* * *}$ & $11.03^{* *}$ & $185.48^{* *}$ & $455.98^{* * *}$ \\
\hline
\end{tabular}

${ }^{1)}$ S, Dumpling shell added 0\% dropwort powder; D1, Dumpling shell 1\% dropwort powder; D3, Dumpling shell 3\% dropwort powder; D5, Dumpling shell 5\% dropwort powder; D7, Dumpling shell 7\% dropwort powder.

${ }^{2}$ Mean \pm SD of three determinations, means with different letters are significantly different at $p<0.05$.

${ }^{* *} \mathrm{p}<0.01, \stackrel{* * *}{\mathrm{k}}<0.001$.

\section{DPPH radical 소거능}

Fig. 1 은 미나리분말 첨가 만두피의 항산화성을 살펴본 결과로 대조군에 비해 미나리 분말 첨가 만두피가 19.30 27.20\%로 미나리 분말 첨가량이 증가할수록 높게 나타났다. 이러한 결과는 미나리 분말 자체의 항산화작용 으로부터 유래한 것으로 사료되며 미나리 분말을 만두피에 첨가시 항산화효과를 높일 수 있을 것으로 사료된다. 부추 및 미나리 분말 첨가 국수(13)의 전자공여능 결과 미나리 분말 $2.5 \%$ 첨가구에서는 16 26\%, 5\% 첨가구에서는 26 30\%로 첨가 함량이 높아질수록 활성이 높게 나타났으 며 미나리 분말을 첨가한 청국장의 항산화 활성 결과(21)에 서도 미나리 첨가량이 증가함에 따라 주요 항산화활성의 성분인 페놀성 화합물의 증가에 따라 비교적 높은 항산화
활성을 나타낸다고 보고한 바 있다. 따라서 기능성 재료를 첨가할수록 만두피의 항산화활성이 높게 나타났으며 만두 피 제조 후에도 남아 있어 만두피의 기능성에 좋은 영향을 줄 것으로 사료된다.

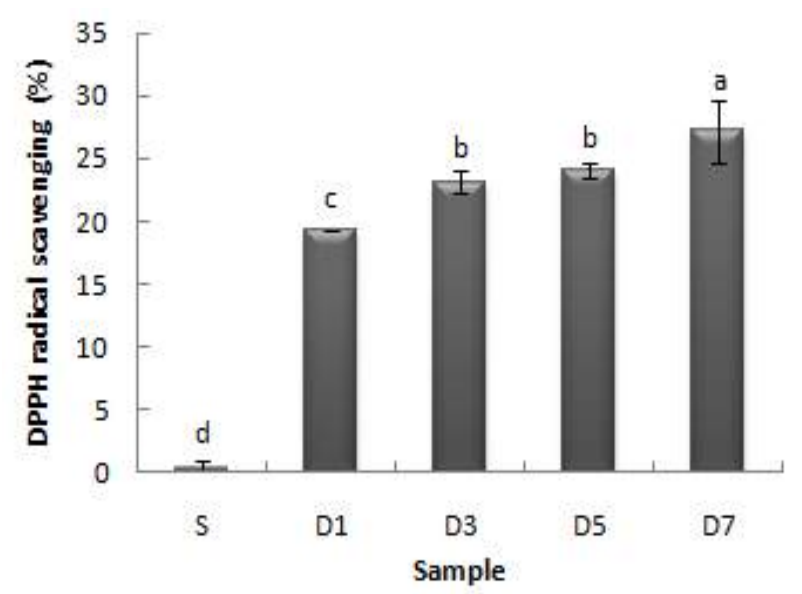

Fig. 1. DPPH radical scavenging activity of the dumpling shell with the addition of dropwort powder

S, Dumpling shell added 0\% dropwort powder; D1, Dumpling shell $1 \%$ dropwort powder, D3, Dumpling shell 3\% dropwort powder, D5, Dumpling shell 5\% dropwort powder; D7, Dumpling shell 7\% dropwort powder. Means with different letters are significantly different at $\mathrm{p}<0.05$.

색 도

미나리 분말 첨가량을 달리하여 제조한 만두피의 색도를 측정한 결과는 Table 5 와 같다. 색의 밝기 정도를 나타내는 명도 L값은 대조군이 68.84로 가장 높게 나타났으며 미나리 분말 첨가량이 증가할수록 $62.84,54.41,50.18,47.18$ 로 감 소되어 만두피의 밝기가 유의적으로 감소하는 경향을 보였 다(p<0.001). 명도의 감소는 첨가된 재료인 미나리 분말인 것으로 사료된다. 적색도인 a값은 대조군이 -1.73 , 미나리 분말 $1 \%$ 첨가 -3.41 , 미나리 분말 $3 \%$ 첨가 -3.40 , 미나리 분말 $5 \%$ 첨가 -1.13 , 미나리 분말 $7 \%$ 첨가 -5.14 로 나타나

Table 5. Hunter's color value of the dumpling shell with the addition of dropwort powder

\begin{tabular}{cccc}
\hline Sample $^{1 \mathrm{l}}$ & $\mathrm{L}$ & $\mathrm{a}$ & $\mathrm{b}$ \\
\hline S & $68.84 \pm 0.72^{\mathrm{a} 2)}$ & $-1.73 \pm 0.60$ & $8.33 \pm 0.91^{\mathrm{e}}$ \\
D1 & $62.84 \pm 1.21^{\mathrm{b}}$ & $-3.41 \pm 0.24$ & $13.81 \pm 0.73^{\mathrm{d}}$ \\
D3 & $54.41 \pm 0.29^{\mathrm{c}}$ & $-3.40 \pm 0.05$ & $18.42 \pm 0.75^{\mathrm{c}}$ \\
D5 & $50.18 \pm 0.34^{\mathrm{d}}$ & $-3.13 \pm 4.74$ & $20.15 \pm 0.61^{\mathrm{b}}$ \\
D7 & $47.18 \pm 0.74^{\mathrm{e}}$ & $-5.14 \pm 0.08$ & $22.62 \pm 0.42^{\mathrm{a}}$ \\
\hline F-value & $447.78^{\text {***}}$ & 1.64 & $194.74^{* * *}$ \\
\hline
\end{tabular}

${ }^{11}$ S, Dumpling shell added 0\% dropwort powder; D1, Dumpling shell $1 \%$ dropwort powder; D3, Dumpling shell 3\% dropwort powder; D5, Dumpling shell 5\% dropwort powder; D7, Dumpling shell 7\% dropwort powder.

${ }^{2}$ Mean $\pm S D$ of three determinations, means with different letters are significantly different at $\mathrm{p}<0.05$ ${ }^{* * *} \mathrm{p}<0.001$. 
모두 음(-)을 나타내어 녹색의 경향을 띠었으며 대조군에 비해 미나리 분말 첨가구가 감소하는 경향을 보였으나 시료 간 유의적인 차이는 없었다. 황색도인 $\mathrm{b}$ 값은 대조군이 8.33 으로 가장 낮은 값을 나타내었으며 미나리 분말 첨가량이 증가할수록 13.81 22.62로 높게 나타나 미나리 분말 7\% 첨가 만두피가 22.62로 유의적으로 가장 높은 값을 보였다 $(\mathrm{p}<0.001)$. 비파잎 분말 첨가 농도가 증가할수록 $\mathrm{L}$ 값과 $\mathrm{a}$ 값 은 감소하고 $\mathrm{b}$ 값은 증가한다고 보고(1)하였으며 미나리 분 말을 첨가한 머핀(11)의 색도에서도 미나리 분말의 첨가량 이 증가할수록 밝기는 감소하고 적색도에서는 녹색이 증가 하는 경향을 보였으며 황색도는 미나리 첨가량이 증가함에 따라 높아진다고 보고하여 본 연구와 일치하였다.

\section{Texture}

미나리 분말 첨가량을 달리하여 제조한 만두피의 조직감 (경도, 탄력성, 응집성, 씹힘성, 부서짐성)을 측정한 결과는 Table 6과 같다. 경도(hardness)는 대조군이 $9.51 \mathrm{~kg} / \mathrm{cm}^{2}$ 로 가장 낮았으며 미나리 분말 첨가량이 많아질수록 10.80 $17.49 \mathrm{~kg} / \mathrm{cm}^{2}$ 로 유의적으로 증가하는 경향을 보였다 ( $<<0.001)$. 이는 새우 분말을 첨가한 만두피 연구(7)에서 새우분말 첨가량이 증가함에 따라 경도는 증가하였음으로 보고하여 본 실험과 유사한 결과는 보였다. 한편 새송이 버섯 분말을 첨가한 만두피(8)의 경도는 버섯 분말의 첨가 군에 비해 대조군이 유의적으로 높게 나타나 본 실험결과와 차이를 보였다. 성분 배합에 따라 만두피의 물성 변화에서 첨가량이 적거나 많이 함유되었을 때 만두피의 경도가 감소 함을 보였다고 보고(21)한 바 있어 본 실험 결과와 상이하였 으나 이는 첨가물의 종류에 따른 차이라고 사료된다. 탄력 성(springiness)은 대조군에 비해 미나리 분말 첨가 만두피 가 유의적으로 높게 나타났으나 $(\mathrm{p}<0.001)$ 미나리 분말 $5 \%$ 첨가까지는 차이를 보이지 않았으며 $7 \%$ 첨가가 $123.55 \%$ 로 가장 높게 나타났다(p<0.001). 응집성(cohesiveness)에서는

Table 6. Texture characteristics of the dumpling shell with the addition of dropwort powder

\begin{tabular}{|c|c|c|c|c|c|}
\hline Sample $^{1)}$ & & & (\%) & Chewiness & (g) \\
\hline & & & & 197. & \\
\hline L & & & & 2 & \\
\hline D3 & & & & 19 & \\
\hline & b & & & 40 & 2 \\
\hline & & . & 10 & 89 & \\
\hline & & & & & \\
\hline \multicolumn{6}{|c|}{$\begin{array}{l}\text { I) S, Dumpling shell added } 0 \% \text { dropwort powder; D1, Dumpling shell } 1 \% \text { dropwort } \\
\text { powder; D3, Dumpling shell } 3 \% \text { dropwort powder; D5, Dumpling shell } 5 \% \text { dropwort } \\
\text { powder; D7, Dumpling shell } 7 \% \text { dropwort powder. } \\
{ }^{2} \text { Mean } \pm \text { SD of three determinations, means with different letters are significantly different } \\
\text { at } p<0.05 \text {. } \\
\text { p }<0.001 \text {. }\end{array}$} \\
\hline
\end{tabular}

미나리 분말 $1 \%$ 첨가가 대조군과 차이 없이 낮은 응집성을 보였으며 미나리 분말 첨가량이 증가할수록 높게 나타났 다. 응집성은 식품의 형태를 구성하는 내부적 결합으로 미 나리분말이 함유하고 있는 단백질과 칼륨, 칼슘, 마그네슘 등의 무기질에 의한 것으로 사료된다. 강황분말을 첨가한 만두피에서도 강황분말 첨가량이 증가할수록 응집성이 높게 나타나 비슷한 경향을 보였다. 씹힘성(chewiness)은 197.09 213.58로 시료 간 유의적인 차이가 없었으며 부서 짐성(brittleness)은 미나리 분말 4\% 첨가까지 21.39 23.33 $\mathrm{g}$ 으로 대조군과 유의적인 차이가 나타나지 않았으나 미나 리 분말 $5 \%$ 이상 첨가 시 높아지는 것으로 나타났다.

\section{관능검사}

미나리 분말 첨가량을 달리하여 제조한 만두피의 관능검 사는 Table 7과 Fig. 2와 같다. Table 7은 만두피에 대한 강도검사(약하다, 연하다 : 0, 강하다, 진하다 : 7)를 실시한 것이며, Fig. 2 는 기호도 검사를 정량적 묘사 분석으로 나타 낸 것이다. 외관 특성에서 색깔(color)은 대조군이 1.18 로 가장 연하게 평가되었으며 미나리 분말 첨가량이 증가할수 록 유의적으로 높아지는 경향을 보였다 $(\mathrm{p}<0.001)$. 표면의 매끄러운 정도(sleekness)에서는 대조군이 5.46으로 가장 높게 나타났으며 미나리 분말 $1 \%$ 첨가>미나리 분말 $5 \%$ 첨가>미나리 분말 3\% 첨가>미나리 분말 $7 \%$ 첨가 순으로 나타났으며 $\mathrm{p}<0.01$ 에서 시료 간 유의한 차이를 보였다. 이 취(off-flavor)에서는 미나리 분말 $3 \%$ 첨가 만두피가 1.73 으 로 가장 낮게 나타났으며 미나리 분말 $7 \%$ 첨가 만두피가 3.73으로 가장 높아 미나리 분말의 첨가량이 너무 많아지면 오히려 향미를 떨어뜨리는 것으로 나타났다. 맛의 특성에 서 밀가루 맛(flour)은 대조군이 5.45로 가장 높게 나타났으 며 미나리 분말 $3 \%$ 이상 첨가 시 유의적으로 감소하는 경향을 보였다( $<<0.001)$. 고소한 맛(savory)에서는 시료 간 유의한 차이는 없었다. 질감의 특성에서 촉촉한 정도 (moistness)는 대조군이 가장 높게 나타났으나 미나리 분말 $5 \%$ 첨가까지 유의적인 차이를 보이지 않고 유사하게 평가 되었으며 미나리 분말 $7 \%$ 첨가 시 촉촉한 정도가 비교적 낮게 평가되었다. 쫄깃한 정도(chewiness)는 미나리 분말 $3 \%$ 첨가와 5.45 로 가장 높았으나 미나리 분말 $1 \%$ 첨가와 $5 \%$ 첨가 만두피에서 미나리 분말 $3 \%$ 첨가 만두피와 비슷한 평가를 받았으며 대조군에 비해 유의적으로 높게 나타났다 $(\mathrm{p}<0.01)$. 치아에 달라붙는 정도(adhesiveness)는 시료 간 유의적인 차이가 없었으며 삼킨 후 느낌(after swallow)에서 는 미나리 분말 $3 \%$ 첨가 만두피가 5.73으로 가장 높게 나타 났으며 미나리 분말 $5 \%$ 첨가>미나리 분말 $1 \%$ 첨가>대조 군>미나리 분말 $7 \%$ 첨가 순으로 나타났다. 전체적인 기호 도를 살펴본 결과(Fig. 2) 외관의 기호도(appearance)에서는 미나리 분말 첨가량이 증가할수록 높게 평가되어 미나리 분말 $7 \%$ 첨가가 가장 높은 점수를 보였다. 최근 다양한 
Table 7. Sensory evaluation of the dumpling shell with the addition of dropwort powder

\begin{tabular}{|c|c|c|c|c|c|c|c|}
\hline \multicolumn{2}{|c|}{ Sample $^{1)}$} & $S$ & D1 & D3 & D5 & D7 & F-value \\
\hline \multirow{2}{*}{$\begin{array}{l}\text { Appea } \\
\text { rance }\end{array}$} & Color & $1.18 \pm 0.40^{22)}$ & $2.63 \pm 0.21^{\mathrm{d}}$ & $3.82 \pm 0.75^{\mathrm{c}}$ & $5.18 \pm 0.98^{b}$ & $6.27 \pm 0.79^{\mathrm{a}}$ & $59.30^{* * *}$ \\
\hline & Sleekness & $5.46 \pm 0.52^{\mathrm{a}}$ & $5.28 \pm 0.47^{\mathrm{ab}}$ & $4.36 \pm 0.62^{\mathrm{bc}}$ & $4.64 \pm 0.36^{\mathrm{ab}}$ & $3.45 \pm 0.36^{\mathrm{c}}$ & $5.40^{* *}$ \\
\hline Flavor & Off-flavor & $2.18 \pm 0.09^{\mathrm{bc}}$ & $2.45 \pm 0.11^{\mathrm{abc}}$ & $1.73 \pm 0.78^{c}$ & $3.27 \pm 0.09^{\mathrm{ab}}$ & $3.73 \pm 0.67^{\mathrm{a}}$ & $2.75^{*}$ \\
\hline \multirow{2}{*}{ Taste } & Flour & $5.45 \pm 1.18^{\mathrm{a}}$ & $4.45 \pm 0.52^{\mathrm{b}}$ & $2.27 \pm 0.78^{\mathrm{c}}$ & $3.09 \pm 0.22^{c}$ & $2.54 \pm 0.03^{\mathrm{c}}$ & $21.22^{* * *}$ \\
\hline & Savory & $4.27 \pm 0.47$ & $4.73 \pm 0.79$ & $5.18 \pm 0.77$ & $4.55 \pm 0.82$ & $3.82 \pm 0.98$ & 2.52 \\
\hline \multirow{3}{*}{ Texture } & Moistness & $5.91 \pm 0.54^{\mathrm{a}}$ & $5.37 \pm 0.50^{\mathrm{a}}$ & $5.64 \pm 0.50^{\mathrm{a}}$ & $5.55 \pm 0.36^{\mathrm{a}}$ & $4.55 \pm 0.93^{b}$ & $4.14^{* \star}$ \\
\hline & Chewiness & $4.73 \pm 0.78^{\mathrm{bc}}$ & $5.36 \pm 0.50^{\mathrm{a}}$ & $5.45 \pm 0.52^{\mathrm{a}}$ & $5.00 \pm 0.63^{\mathrm{ab}}$ & $4.36 \pm 0.81^{\mathrm{c}}$ & $5.10^{* *}$ \\
\hline & Adhesiveness & $3.73 \pm 0.95$ & $4.09 \pm 0.44$ & $3.91 \pm 0.51$ & $3.63 \pm 0.92$ & $3.27 \pm 0.78$ & 0.54 \\
\hline \multicolumn{2}{|c|}{ After swallow } & $4.55 \pm 0.93^{\mathrm{bc}}$ & $4.82 \pm 0.87^{b}$ & $5.73 \pm 0.27^{\mathrm{a}}$ & $5.09 \pm 0.83^{\mathrm{ab}}$ & $4.00 \pm 0.05^{\mathrm{c}}$ & $5.73^{* * *}$ \\
\hline
\end{tabular}

${ }^{1)}$ S, Dumpling shell added 0\% dropwort powder; D1, Dumpling shell 1\% dropwort powder; D3, Dumpling shell 3\% dropwort powder; D5, Dumpling shell 5\% dropwort powder; D7, Dumpling shell $7 \%$ dropwort powder.

${ }^{2)}$ Means with different letters are significantly different at $\mathrm{p}<0.05$

$\mathrm{p}<0.05{ }^{* *} \mathrm{p}<0.01,{ }^{* * *} \mathrm{p}<0.001$.

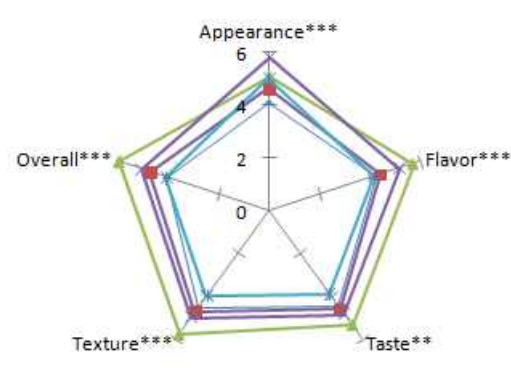

$$
\rightarrow \mathrm{S}-\mathrm{m}-\mathrm{D} 1 \rightarrow \mathrm{D} 3 \multimap \mathrm{D} 5 \rightarrow \mathrm{D} 7
$$

Fig. 2. QDA profile of the acceptability of dumpling shell with the addition of dropwort powder

S, Dumpling shell added 0\% dropwort powder; D1, Dumpling shell $1 \%$ dropwort powder; D3, Dumpling shell 3\% dropwort powder; D5, Dumpling shell 5\% dropwort powder; D7, Dumpling shell $7 \%$ dropwort powder.

$\mathrm{p}<0.01,{ }^{* * *} \mathrm{p}<0.001$

기능성 원료들을 사용하여 제조된 유색 제품에 대한 소비자 의 선호도가 높아지면서 전통적인 흰색에 대한 고정관념에 서 탈피하는 경향(23)을 보이는 데 본 결과도 이러한 경향을 반영한 것으로 사료된다. 향미(flavor)에 대한 기호도에서 는 미나리 분말 $3 \%$ 첨가가 5.73 으로 미나리 분말 $5 \%$ 첨가까 지 비슷한 평가를 보였으며 이를 제외한 시료에서는 유의적 으로 감소하는 경향을 보였다. 맛(taste)에 대한 기호도에서 는 미나리 분말 $3 \%$ 첨가 $5.36,5 \%$ 첨가 $4.82,1 \%$ 첨가 4.60 , 대조군 $4.45,7 \%$ 첨가 3.91 순으로 나타났으며 $\mathrm{p}<0.01$ 에서 유의한 차이를 나타내었다. 미나리 분말 첨가 만두피의 맛 에서는 너무 많은 미나리 분말의 첨가는 오히려 맛을 떨어 뜨리는 것으로 보여 적정한 농도가 필요하리라 사료된다. 질감(texture)의 기호도는 미나리 분말 $3 \%$ 첨가 만두피가 5.82 로 가장 높게 평가되었으며 $7 \%$ 첨가 만두피에서는 가 장 낮은 기호도를 보였다. 전체적인 기호도(overall)에서는
미나리 분말 $3 \%$ 첨가 만두피가 6.00 으로 가장 높게 나타났 으며 미나리 분말 $5 \%$ 첨가 $5.09,1 \%$ 첨가 4.73 , 대조군과 미나리 분말 $7 \%$ 는 4.09 로 나타나 미나리 분말의 적정량을 만두피에 첨가 시 외관 및 관능적 특성이 향상되는 것으로 나타났다. 전반적으로 바람직한 정도로 밀가루 대체 미나 리 분말 $3 \%$ 첨가군의 기호도가 가장 높게 평가되었다.

\section{요 약}

본 연구는 생리 활성 기능을 지닌 미나리를 이용한 다양 한 가공제품의 개발 및 미나리의 활용성 증대의 일환으로 미나리 분말 첨가에 따른 만두피의 제조 및 품질특성에 대하여 살펴보았다. 밀가루 대체 미나리분말 $0,1,3,5$, $7 \%$ 를 첨가하여 만두피를 제조한 결과 수분결합력은 미나 리 분말이 첨가될수록 증가하였으며 수분함량은 미나리 분말 첨가량에 따른 유의적인 차이는 없었다. 만두피의 조 리 특성에서는 무게와 수분흡수율과 부피는 대조군에 비하 여 미나리 분말 첨가구가 높게 나타났으며 미나리 분말 첨가량이 많아짐에 따라 유의적으로 증가하는 경향을 보였 다(p<0.001). 탁도는 미나리 분말 $7 \%$ 첨가 만두피가 가장 높게 나타났으며 미나리 분말 첨가량이 증가할수록 용출성 분이 유의하게 증가하였다 $(\mathrm{p}<0.001)$. 미나리 분말 첨가 만 두피의 DPPH radical 소거능은 미나리 분말 첨가량이 증가 할수록 높게 나타났으며 색도에서는 미나리 분말 첨가량이 증가할수록 $\mathrm{L}$ 값과 $\mathrm{a}$ 값은 감소하였으며 $\mathrm{b}$ 값은 증가하였다. Texture에서 경도는 대조군에 비해 미나리 분말 첨가구가 높게 나타났으며 탄력성과 응집성은 미나리 분말 첨가량이 증가할수록 유의적으로 높게 나타났다( $\mathrm{p}<0.001)$. 외관의 기 호도에서는 미나리 분말이 많이 첨가될수록 선호도가 높았 으며 향미, 맛, 질감, 전체적인 기호도에서 미나리 분말 $3 \%$ 
첨가 만두피가 기호도면에서 우수하게 평가되어 기능성과 기호적인 측면에서 도움을 줄 수 있는 만두피로 사용 될 수 있을 것이라 사료된다.

\section{Reference}

1. Park ID (2012) Quality characteristics of dumpling shells containing loquat leaf powder. J East Asian Soc Dietary Life, 22, 795-801

2. Bok HJ (2008) The a literary investigation on mandu type and cooking methods of mandu during the Josen era (1400's 1600's). Korean J Food Culture, 23, 252-257

3. Chang HJ, Hwang YK (2006) Product development and market testing of ready-to-eat mandu with pond-snail as a health food. Korean J Community Nutrition, 11, 650-660

4. Park BH, An SA, Cho HS (2014) Quality characteristics of mandupi added with Curcuma atomatica powder. Korean J Food Culture, 29, 348-354

5. Cho HS, Kim KH (2008) Quality characteristics of mandupi with skate (Raja kenojer) flour. Korean J Food Culture, 23, 252-257

6. Pyun JW, Nam HW, Woo IA (2001) A study on the characteristics of mandupi differing in roasted soy flour content. Korean J Food Nutr, 14, 287-292

7. Kim KH, Park GH, Cho YJ, Kim SR, Cho HS (2009) Quality characteristics of shrimp flour added dumpling shell. Korean J Food Culture, 24, 206-211

8. Park BH, Ju SM, Cho HS (2010) Effect of Enteromorpha intenstinalis powder addition in the quality of dumpling shell. Korean J Food Preserv, 17, 814-819

9. Kang BH, Shin EJ, Lee SH, Lee DS, Hur SS, Kim SH, Son SM, Lee JM (2011) Quality characteristics of dumpling shell containing Pleurotus eryngii powder. J Korean Soc Food Sci Nutr, 40, 570-574

10. Seo JS (2013) Quality characteristics of dumpling shell with Curcuma longa L. powder added. Korean J Food Preserv, 20, 621-627

11. Seo EO, Kim KH, Ko SH (2011) Quality characteristics of muffins containing domestic dropwort powder (Oenanthe stolonifera D.C.). J East Asian Soc Dietary Life, 21, 338-344
12. Hwang CR, Hwang IG, Kim HY, Kang TS, Kim YB, Joo SS, Lee JS, Jeong HS (2011) Antioxidant component and activity of dropwort ethanol extracts. J Korean Soc Food Sci Nutr, 40, 316-320

13. Son MG, Cha CG, Park JH, Kim CS, Lee SP (2005) Manufacture of dropwort extract using brown sugar fructose syrup and oligosaccharides. J Korean Soc Food Sci Nutr, 34, 1485-1489

14. Kim CB, Lee SH, Kim MY, Yoon JT, Cho RK (2002) Effect of addition of leak and dropwort powder on quality of noodles. Korean J Food Preserv, 9, 36-41

15. Park SJ, Lee KS, An HL (2007) Effects of dropwort powder on the quality of castella. J East Asian Soc Dietary Life, $17,834-839$

16. Sung KH, Hong JS, Seo BH, Choi JJ (2010) A study of the quality characteristics of sulgidduk added with dropwort powder. J East Asian Soc Dietary Life, 20, 589-595

17. AOAC (1995) Official Method of Analysis. $16^{\text {th }}$ ed, Association of Official Analysis Chemists, Washinhton DC, $p$ 1-43

18. Oh BY, Lee YS, Kim YO, Kang JH, Jung KJ, Park JH (2010) Quality characteristics of dried noodles prepared by adding Hericium erinaceum powder and extract. Korean J Food Sci Technol, 42, 714-720

19. Lee YS, Lim NY, Lee KH (2000) A study on the preparation and evaluation of dried noodle products made from composite flours utilizing arrowroot starch. Korean J Soc Food Sci, 16, 59-66

20. Park BH, Cho HS (2006) Quality characteristics of dried noodles made with Dioscorea japonica flour. Korean J Food Cookery Sci, 22, 173-180

21. Lee SH, Kim JH (2013) Fermentation and quality characteristics of cheonggukjang with addition of dropwort (Oenanthe stolonifera D.C.) powder. J Korean Soc Food Sci Nutr, 42, 1133-1138

22. Kang KS, Kim BS (2003) Changes of rheology on the dumpling shell by added materials. Korean J Food Preserv, 10, 498-505

23. Hong SP, Jun HI, Song GS, Kwon KS, Kwon YJ, Kim YS (2004) Characteristics of wax gourd juice-added dry noodles. Korean J Food Sci Technol, 36, 795-799 